\title{
The "Three Italy" of the COVID-19 epidemic and the possible involvement of SARS-CoV-2 in triggering complications other than pneumonia
}

\author{
Carla Prezioso $^{1,2} \cdot$ Maria Elena Marcocci ${ }^{2} \cdot$ Anna Teresa Palamara $^{3,4} \cdot$ Giovanna De Chiara $^{5} \cdot$ Valeria Pietropaolo $^{2}$ (D)
}

Received: 19 May 2020 / Revised: 19 May 2020 / Accepted: 25 May 2020 / Published online: 16 June 2020

(C) The Author(s) 2020

\begin{abstract}
Coronavirus disease 2019 (COVID-19), first reported in Wuhan, the capital of Hubei, China, has been associated to a novel coronavirus, the severe acute respiratory syndrome coronavirus 2 (SARS-CoV-2). In March 2020, the World Health Organization declared the SARS-CoV-2 infection a global pandemic. Soon after, the number of cases soared dramatically, spreading across China and worldwide. Italy has had 12,462 confirmed cases according to the Italian National Institute of Health (ISS) as of March 11, and after the "lockdown" of the entire territory, by May 4, 209,254 cases of COVID-19 and 26,892 associated deaths have been reported. We performed a review to describe, in particular, the origin and the diffusion of COVID-19 in Italy, underlying how the geographical circulation has been heterogeneous and the importance of pathophysiology in the involvement of cardiovascular and neurological clinical manifestations.
\end{abstract}

Keywords COVID-19 - SARS-CoV-2 - Italy geographical circulation · Pathophysiology · Cardiovascular manifestations · Neurological implications

\begin{tabular}{|c|c|c|}
\hline \multirow{2}{*}{\multicolumn{3}{|c|}{ Abbreviations }} \\
\hline & & \\
\hline \multicolumn{2}{|c|}{ COVID-19 } & Coronavirus disease 2019 \\
\hline \multicolumn{2}{|c|}{ SARS-CoV-2 } & $\begin{array}{l}\text { Severe acute respiratory syndrome } \\
\text { coronavirus } 2\end{array}$ \\
\hline \multicolumn{2}{|c|}{ ISS } & Italian National Institute of Health \\
\hline \multicolumn{2}{|c|}{ WHO } & World Health Organization \\
\hline \multirow{2}{*}{\multicolumn{2}{|c|}{ SARS-CoV }} & Severe acute respiratory \\
\hline & & syndrome coronavirus \\
\hline \multicolumn{3}{|c|}{$\begin{array}{l}\text { Giovanna De Chiara and Valeria Pietropaolo contributed equally to this } \\
\text { work. }\end{array}$} \\
\hline$\square$ & \multicolumn{2}{|c|}{$\begin{array}{l}\text { Valeria Pietropaolo } \\
\text { valeria.pietropaolo@uniroma1.it }\end{array}$} \\
\hline 1 & \multicolumn{2}{|c|}{$\begin{array}{l}\text { Microbiology of Chronic Neuro-degenerative Pathologies, IRCSS } \\
\text { San Raffaele Pisana, Rome, Italy }\end{array}$} \\
\hline 2 & \multicolumn{2}{|c|}{$\begin{array}{l}\text { Department of Public Health and Infectious Diseases, "Sapienza" } \\
\text { University, P.le Aldo Moro, 5, } 00185 \text { Rome, Italy }\end{array}$} \\
\hline 3 & \multicolumn{2}{|c|}{$\begin{array}{l}\text { Department of Public Health and Infectious Diseases, Laboratory } \\
\text { affiliated to Istituto Pasteur Italia - Fondazione Cenci Bolognetti, } \\
\text { Sapienza University of Rome, Rome, Italy }\end{array}$} \\
\hline \multicolumn{3}{|c|}{ IRCCS San Raffaele Pisana, Telematic University, Rome, Italy } \\
\hline 5 & $\begin{array}{l}\text { Institute of T } \\
\text { Rome, Italy }\end{array}$ & nslational Pharmacology, National Research Council, \\
\hline
\end{tabular}

Abbreviations

COVID-19

Severe acute respiratory syndrome

Italian National Institute of Health

WHO

Severe acute respiratory

syndrome coronavirus

Giovanna De Chiara and Valeria Pietropaolo contributed equally to this

Valeria Pietropaolo

valeria.pietropaolo@uniroma1.it

Microbiology of Chronic Neuro-degenerative Pathologies, IRCSS

San Raffaele Pisana, Rome, Italy

MERS-CoV

ARDS

RT-PCR

CT

CoVs

$\mathrm{N}$

$\mathrm{S}$

HE

M

E

ORFs

nsps

CRS

VEGF

ACE2

RAAS

AngII

ACEs

TMPRSS2

CMCs

CVDs

TnT
Middle East respiratory syndrome coronavirus Acute respiratory distress syndrome Reverse-transcription polymerase chain reaction Chest computed tomography Coronaviruses Phosphorylated nucleocapsid

Spike

Hemagglutinin-esterase

Membrane

Envelope

Open reading frames

Non-structural proteins

Cytokine release syndrome

Vascular endothelial growth factor

Angiotensin-converting enzyme 2

Renin-angiotensin-aldosterone system

Angiotensin II

Specific angiotensin-converting enzymes

Transmembrane serine protease 2

Cardiomyocytes

Cardiovascular diseases

Troponin $\mathrm{T}$ 


\section{CNS Central nervous system \\ BBB Blood-brain barrier \\ CSF Cerebrospinal fluid \\ IAV Influenza A virus \\ KDSS Kawasaki disease shock syndrome \\ MAS Macrophage activation syndrome \\ HCoV-NH New Haven coronavirus}

\section{Introduction}

Coronavirus disease 2019 (COVID-19), a highly infectious disease caused by severe acute respiratory syndrome coronavirus 2 (SARS-CoV-2) was firstly reported in Wuhan, Hubei Province, China, in December 2019 and rapidly spread to other cities and countries beyond China (Zhu et al. 2020). The beginning of the infection started from the Huanan seafood wholesale market, while the exact infection route of the first case remains unclear (Paules et al. 2020). In the early stages of the global COVID-19 spread, the cases identified outside of China were mostly travelers who were infected in China and then moved to areas outside of the country. From mid-February 2020, COVID-19 has begun to spread in South Korea, Italy, Iran, and Japan, and the World Health Organization (WHO) declared this ongoing outbreak as a global public health emergency (WHO Coronavirus disease 2019a). On the March 11, 2020, COVID-19 has been defined as a pandemic (WHO Coronavirus disease 2019b). Currently, SARS-CoV-2 has spread to all continents excluding Antarctica. As of May 11, 2020, a total of 4,006,257 COVID-19 cases with 278,892 deaths were confirmed, among which 44,533 cases were from Africa, 1,702,451 cases were from Americas, 1,731,606 cases were from Europe, 100,881 cases were from South-East Asia, and, finally, 160,910 cases were from Western Pacific (World Health Organization 2020).

This article gives a bird's eye view about the origin, spread, features, and related emerging complications of COVID-19 disease, focusing on the situation in Italy.

\section{Origin and spread of COVID-19 in Italy}

The first cases of COVID-19 had been reported in Central Italy, in Rome. The subjects were tourists from Wuhan who had traveled in Lombardy, a Northern region of Italy. The first autochthonous diagnosed case, in the Italian territory, was reported on the February 20, 2020, in a 38-year-old man from the city of Codogno (Lombardy) with no travel history to known areas of viral infection or relation to a probable or confirmed COVID-19 case. After the case in Codogno, other people in Lombardy with flu-like symptoms were found positive for SARS-CoV-2, including medical staff. Thereafter, the Italian COVID-19 epidemic has been mainly characterized by a local transmission. Since the beginning of the epidemic, several preventive measures to favor "social distancing" were undertaken, initially at the local level and finally at the national level with a lockdown of the entire territory on March 11, 2020 (Italian Ministry of Health Covid-19 2020). Geographical spread of the COVID-19 has been heterogeneous with a substantial gradient at the latitude levels with the highest spread in the Northern regions and the lowest in the Southern regions and in the main Islands. The region of Lombardy has the highest number of cases of SARS-CoV-2 and appears to be the epicenter of the Italian outbreak, unlike regions like Molise, Basilicata, and Sardinia, where the SARS-CoV-2 circulation has been encompassed (Italian National Institute of Health (ISS) and National Institute of Statistics 2020) (Fig. 1). According to the Italian National Institute of Health (ISS), by May 4 in Italy, there were 209,254 cases of COVID-19 and 26,892 associated deaths (Italian National Institute of Health (ISS) 2020) (Fig. 2). The last evaluation of the Imperial College COVID-19 Response Team estimated that the infected patients in Italy should be about 9\% (95\% CI 3.2-26) of the total population (Ferguson et al. 2020). Although cases were more common among women $(53.1 \%)$, mainly among the elderly population, lethality is higher in male subjects (Fig. 3). The median age at COVID-19 diagnosis was 62 years old. Around 35\% of reported COVID19 cases had at least one diagnosed comorbidity reported: cardiovascular, respiratory, diabetes, immune system deficit, metabolic, cancer, and renal comorbidities (Italian National Institute of Health (ISS) and National Institute of Statistics 2020) SARS-CoV-2 mortality rate (3.8\%) (Report of the WHO-China Joint Mission on Coronavirus Disease 2019) is lower than that of other members of Coronaviridae family, such as severe acute respiratory syndrome coronavirus (SARS-CoV) (10\%) [World Health Organization (WHO). Summary of probable SARS cases with onset of illness from 1 November 2002 to 31 July. (World Health Organization (WHO) 2020) or Middle East respiratory syndrome coronavirus (MERS-CoV) (37.1\%) (WHO Middle East respiratory syndrome coronavirus (MERS-CoV) 2019), although the number of relative infection cases is more than 10 times higher.

Considering only the month of March, the average national level shows an increase in deaths due to the total causes of 49.4\%. If we take as a reference the period from the first COVID-19 death reported by the COVID-19 ISS (February 20) until March 31, deaths increase although the strong concentration of the phenomenon in some areas of the country "flatten" the size of the impact of the COVID-19 epidemic on total mortality (Italian National Institute of Health (ISS) 2020)

Specifically, $91 \%$ of the excess mortality registered at the average national level in March 2020 is concentrated in the areas of high spread of the epidemic: 37 northern 
Fig. 1 The "Three Italy" of the COVID-19 epidemic. The highest geographical SARS-CoV-2 spread was reported in the northern regions of Italy and the lowest in the southern regions and in the main Islands. The region of Lombardy has the highest number of cases of SARS-CoV-2 and appears to be the epicenter of the Italian outbreak, unlike regions like Molise, Basilicata, and Sardinia, where the SARS-CoV-2 circulation has been encompassed

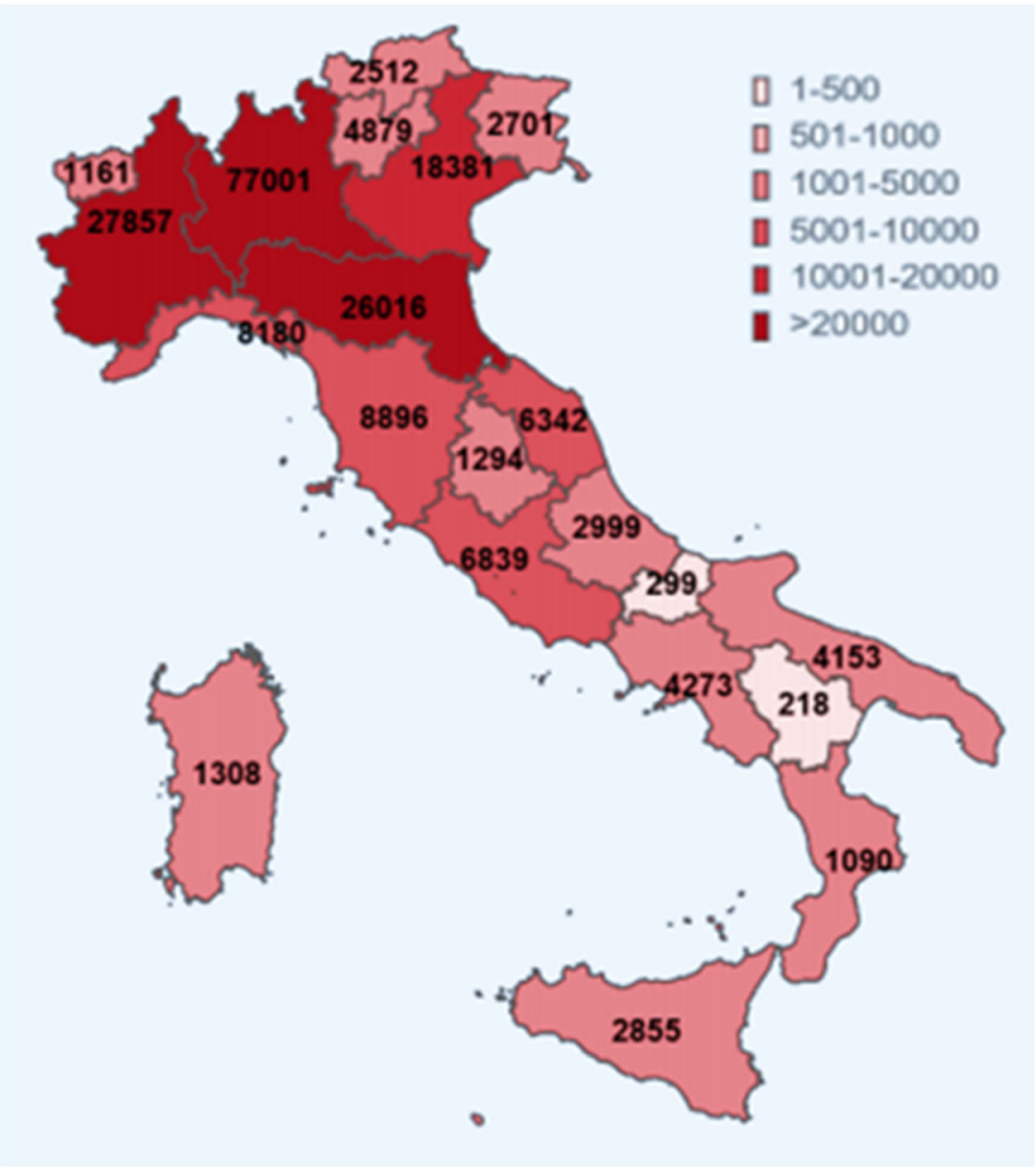

provinces plus Pesaro and Urbino. In all of these provinces, deaths from all causes have more than doubled compared to the 2015-2019 average for the month of March. If we consider the period from February 20 to March 31, 52\% are deaths reported by the COVID-19 ISS (Italian National Institute of Health (ISS) 2020)
In the areas with medium spread of epidemic ( 35 provinces mainly located in the Center-North), death increase due to the total causes in the period from February 20 to March 31 is much more contained: $47 \%$ are attributed to COVID-19 positive deaths. Finally, in the areas with a low spread of epidemic (34 provinces mostly located in the Center and in the South),
Fig. 2 Cases of infected patients and associated deaths. According to the Italian National Institute of Health (ISS), by May 4 in Italy, there were 209,254 cases of COVID-19 and 26,892 associated deaths

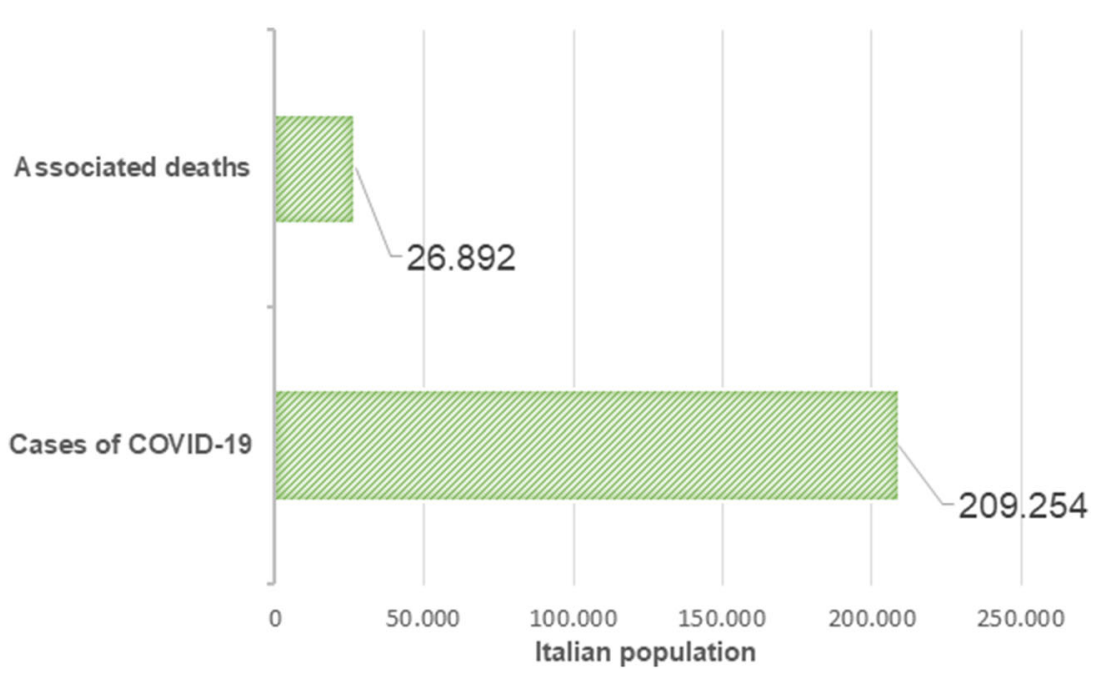


Fig. 3 Cases of SARS-CoV-2 infected patients in female and male gender. SARS-CoV-2 was more common among women $(53.1 \%)$ than among man (46.9\%), although lethality is higher in male subjects

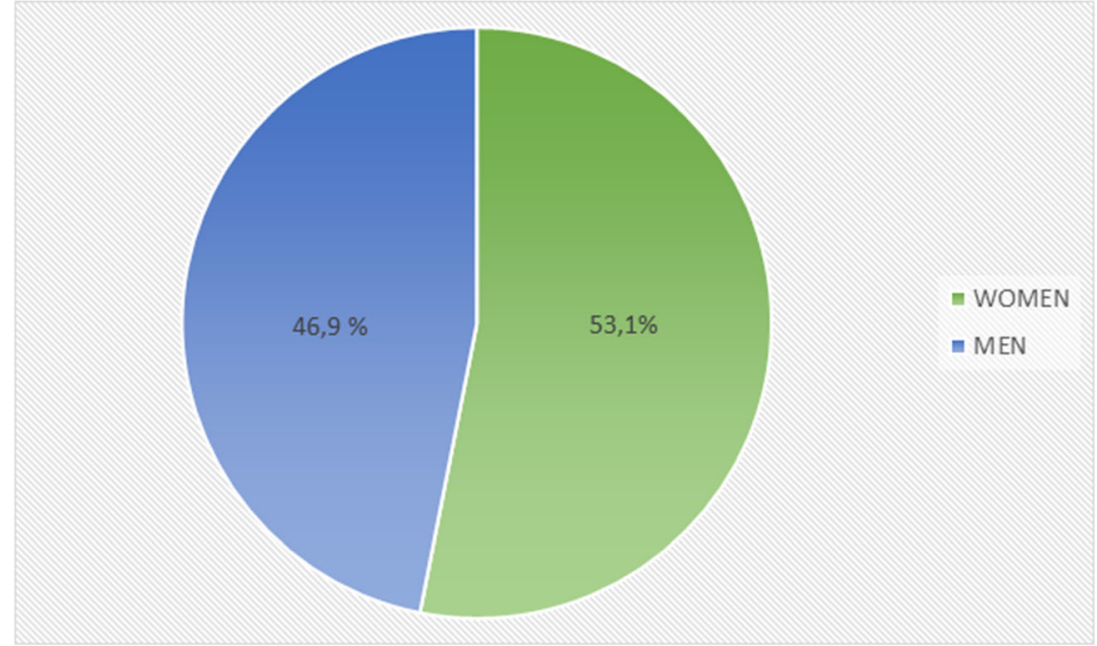

deaths of the month of March 2020 are on average 1.8\% lower than that of the last 5 years.

\section{Transmission, symptoms, and diagnosis}

Infection is transmitted from human to human and through contact with contaminated environmental surfaces. Respiratory droplets and contact transmission are considered to be the main transmission routes. Recent reports indicate that SARS-CoV-2 can be detected in the urine and stool of laboratory confirmed patients, implying a risk of fecal-oral transmission (General Office of National Administration of Traditional Chinese Medicine n.d.). Moreover, there is still no evidence that SARS-CoV-2 can be transmitted through aerosols or from mother to baby during pregnancy or childbirth (Yuefei et al. 2020). COVID-19 patients are the main source of infection, and severe patients are considered to be more contagious than mild ones. Asymptomatically infected persons or patients in incubation, without signs or symptoms of respiratory infection, proven to shed infectious virus, may also be potential sources of infection (Bai et al. 2020; Pan et al. 2020; Rothe et al. 2020). These features may explain the sudden epidemic spreading of the virus.

The clinical spectrum of COVID-19 symptoms varies from asymptomatic/pauci-symptomatic forms to clinical conditions, characterized by severe respiratory failure, that necessitates mechanical ventilation and support in an intensive care unit, to multiorgan and systemic manifestations, characterized by sepsis, septic shock, and multiple organ dysfunction syndromes (Lupia et al. 2020). Pneumonia appears to be the most frequent manifestation of infection, with fever, cough, dyspnea, and bilateral infiltrates on chest imaging revealing invasive lesions in both lungs (Yang and Jin, 2020). Other common clinical manifestations included fever, cough, fatigue, sputum production, shortness of breath, sore throat, headache, and olfactory and gustative disorders (Guan et al. 2020a; Guan et al. 2020b). In addition, a part of patients manifested gastrointestinal symptoms, with diarrhea and vomiting, and in some patients, they may be presenting complaint (Chan et al. 2020; Huang et al. 2020). Whether upper respiratory symptoms and gastrointestinal symptoms were rare, fever and cough represented the main symptoms, suggesting the differences in viral tropism as compared with SARS-CoV, MERS-CoV, and influenza virus (Assiri et al. 2013; Lee et al. 2003; Wang et al. 2016).

In severe cases, elderly and subjects with underlying disorders (i.e., hypertension, chronic obstructive pulmonary disease, diabetes, cardiovascular disease) could develop acute respiratory distress syndrome (ARDS), septic shock, metabolic acidosis, and coagulation dysfunction, leading to the death (Huang et al. 2020a). Molecular-based approaches are the first line of methods to confirm SARS-CoV-2-suspected infection. Specifically, reverse-transcription polymerase chain reaction (RT-PCR) is used to detect the nucleic acid of SARS-CoV-2 in sputum, throat swabs, and secretions of the lower respiratory tract samples (Lippi et al. 2020). Although nucleic acid testing is the gold standard technique for laboratory diagnosis, other methods such as virus antigen or serological antibody testing are also valuable assays (Chen et al. 2015; Meyer et al. 2014). A positive test for SARS-CoV-2 generally confirms the diagnosis of COVID-19, although false-positive tests are possible. If initial testing is negative but the suspicion for COVID-19 remains, the WHO recommends resampling and testing from multiple respiratory tract sites(World Health Organization Coronavirus Disease (COVID-19)). Imaging findings of chest computed tomography $(\mathrm{CT})$ in patients with COVID-19 most commonly demonstrate ground-glass opacification with or without consolidative abnormalities, consistent with viral pneumonia. Other studies have suggested that chest CT abnormalities are more likely to be bilateral, have a peripheral distribution, and involve the lower lobes. 
Chest CT may be helpful in making the diagnosis, but no finding can completely rule in or rule out the possibility of COVID-19. Negative RT-PCR tests on oropharyngeal swabs despite CT findings suggestive of viral pneumonia have been reported in some patients who ultimately tested positive for SARS-CoV-2. Serologic tests should be able to identify patients who have either current or previous infection but a negative PCR test (Lim et al. 2020; Ling et al. 2020). Previous studies have demonstrated that the development of antibody response to infection can be host dependent and take time; in the case of SARS-CoV-2, the majority of patients seroconvert between 7 and 11 days post-exposure to the virus, although some patients may develop antibodies sooner (Patel et al. 2020). As a result of this natural delay, antibody-detecting tests for SARS-CoV-2 are not useful for the diagnosis of an acute illness but might be important for understanding the diffusion of Sars-CoV-2 in symptomatic or paucisymptomatic patients.

\section{Virus and pathophysiology}

SARS-CoV-2, taxonomically, has been classified as Betacoronavirus (lineage B) by the WHO (Zhu et al. 2020). Genetic sequence analysis showed more than $50 \%$ homology to MERS-CoV and $80 \%$ to SARS-CoV and both originate in bats. The differences between the sequences are mainly in the ORF1a gene and the spike gene, encoding S-protein, which is the key protein for the interaction between coronavirus and host cells (Lu et al. 2020; Zhou et al. 2020; Zhu et al. 2020). The coronaviruses (CoVs) family is a class of enveloped, positive-sense single-stranded RNA viruses having an extensive range of natural roots. These viruses can cause respiratory, enteric, hepatic, and cardiovascular diseases (de Wilde et al. 2018; Weiss and Leibowitz 2011; Zheng et al. 2020). SARS-CoV-2 virion presents a genome size of $29.9 \mathrm{~kb}$ [Available via http://nmdc.cn/coronavirus] with a nucleocapsid composed of genomic RNA and phosphorylated nucleocapsid $(\mathrm{N})$ protein. The nucleocapsid is covered by an envelope with the spike (S) glycoprotein trimmer, which exists in all CoVs, and the hemagglutininesterase (HE), only expressed from some CoVs. Moreover, in the viral envelope, located among the $\mathrm{S}$ protein, are confined the membrane $(\mathrm{M})$ and the envelope $(\mathrm{E})$ proteins $(\mathrm{Wu}$ et al. 2020). The SARS-CoV-2 genome contains a variable number of open reading frames (ORFs) (Song et al. 2019) encoding for structural proteins, including $\mathrm{S}, \mathrm{M}, \mathrm{E}, \mathrm{N}$ proteins and accessory proteic chains (Lei et al. 2018; Letko et al. 2020). To address the pathogenetic and virulence mechanisms of SARS-CoV-2, the role of structural and non-structural proteins (nsps) must be considered (Letko et al. 2020). Four structural proteins are essential for virion assembly and infection of CoVs (Di Gennaro et al. 2020). S protein, present on the viral surface as a trimer, is the primary determinant of viral tropism and is responsible for receptor binding and membrane fusion (Beniac et al. 2006; Delmas and Laude 1990). The M protein has three transmembrane domains. It shapes the virions, promotes the curvature of the membrane, and binds to the nucleocapsid (Nal et al., 2005; Neuman et al. 2011). Regarding the E protein, it plays a role in virus assembly, release and viral pathogenesis (DeDiego et al. 2007; Nieto-Torres et al. 2014). Finally, the N protein contains two domains, both of which can bind virus RNA genome via different mechanisms. It is reported that $\mathrm{N}$ protein can bind to nsp3 protein packaging the encapsidated genome into virions (Chang et al. 2006; Fehr and Perlman, 2015; Hurst et al. 2009). Moreover, $\mathrm{N}$ is also an antagonist of interferon and viral encoded repressor of RNA interference, which appears to be beneficial for the viral replication (Cui et al. 2015). Among nsps, most of these proteins, specifically nsp 1 to 16 , displayed a specific role in $\mathrm{CoVs}$ replication and in blocking the host innate immune response (Cascella et al. 2020; Guo et al. 2020). The pathogenic mechanism that starts with SARS-CoV-2 infection and culminates in pneumonia and heart or other extensive tissue damage seems to be particularly complex and able to produce an overreaction of the immune system associated with a pronounced cytokine storm, also known as cytokine release syndrome (CRS). Clinical features include extremely elevated cytokine levels (IL-6, IL-10, and TNF- $\alpha$ ), lymphopenia (in CD4+ and CD8+ T cells), decreased IFN- $\gamma$ expression in CD4+ T cells, and an increase in Th17 cell proportion. Th17 cells are helper T cells differentiated from Th 0 cells mainly stimulated by IL- 6 and IL-23. Specifically, IL-6, an important member of the cytokine network and produced by activated macrophages, plays a central role in acute inflammation with its antiinflammatory and pro-inflammatory effects. Biologically, IL-6 promotes $\mathrm{T}$ cell population proliferation and activation and $\mathrm{B}$ cell differentiation, regulates acute phase response, and affects the hormone-like properties of vascular disease, lipid metabolism, insulin resistance, mitochondrial activity, neuroendocrine system, and neuropsychological behavior (Chen et al. 2020a; Pyle et al. 2017). On the other end, IL-6 increases during inflammatory and cardiovascular diseases (myocardial ischemia, coronary atherosclerosis, angina pectoris, congestive heart failure, hypertension), infections, autoimmune disorders, and some types of cancer (Bennardo et al. 2020). During the spread of infection, SARS-CoV-2 could cross through the mucous membranes, especially nasal and larynx mucosa; enters the lungs through the respiratory tract (Bennardo et al. 2020; Rose-John 2018; Chen et al. 2020b); and could cause the aggravation of patient's condition in 7 to 14 days after onset. B lymphocyte reduction may occur early during the disease and may affect antibody production in patients. Elevated IL-6 levels were observed in patients infected by SARS-CoV-2 and were correlated with the exacerbation of the disease around 2 to 10 days after onset (Di Gennaro et al. 
2020). Excessive IL-6 signaling leads to a many of biological effects, such as maturing naïve T cells into effector $T$ cells, the induction of vascular endothelial growth factor (VEGF) expression in epithelial cells, the increase of vessel permeability, and reducing myocardium contractility, culminating in organ damage (Pathan et al. 2004; Tanaka et al. 2016). Since elevated IL-6 levels were consistently reported during COVID-19 and were correlated with higher mortality in these patients, IL6 might serve as a predictive biomarker for COVID-19 severity.

\section{The role of angiotensin-converting enzyme 2 (ACE2)}

Different organ systems are believed to participate in COVID19 due to the wide range expression of the primary SARSCoV-2 entry receptor, angiotensin-converting enzyme 2 (ACE2) (Fig. 4).

ACE2 is particularly expressed on the type II alveolar epithelial cells (Guan et al. 2020a; Guan et al. 2020b; Wang and $\mathrm{Xu}$ 2020; Yang et al. 2020a; Yang et al. 2020b; Yang et al. 2020c; Zhao et al. 2020) although also the gastrointestinal tract, kidneys, heart, brain stem, vasculature, liver, and nasal and oral mucosa express these receptors, contributing to extrapulmonary manifestations (Zhao et al. 2020). However, the different distribution of ACE2 in organs and tissue is significantly correlated to the clinical symptoms of SARS-CoV-2 infection (Nejadi Babadaei et al. 2020) (Fig. 4).

In addition to functional receptor role, physiologically, ACE2 is an important modulator of the renin-angiotensinaldosterone system (RAAS), which systemically regulates, via distinct hormones, the cardiovascular and immune systems and is involved in heart function and in the development of hypertension and diabetes mellitus. Briefly, the prorenin is cleaved in the kidneys, and then, the activated renin is released into the blood stream where it in turn activates angiotensinogen, which is converted into angiotensin I and finally into angiotensin II (AngII). Specific angiotensinconverting enzymes (ACEs), mainly expressed on renal and pulmonary epithelium, facilitate this activation cascade. ACE2 is a well-characterized negative regulator of the RAAS system as it converts AngII into the vasodilatory fragment Ang 1-7, which simultaneously decreases the AngII concentration to facilitate the antihypertensive effect (Keidar et al. 2007; Santos et al. 2018).

\section{COVID-19 and cardiovascular manifestations}

ACE2, located also on the cell surface of cardiac systems, may help to understand those patients infected by SARS-CoV-2 that presented cardiovascular symptoms (myocardial injury, cardiac chest pain, fulminant heart failure, cardiac arrhythmias, and cardiac death), in addition to the typical respiratory symptoms during COVID-19 (Long et al. 2020) (Fig. 4). The mechanism for the SARS-CoV-2 intracellular entry involves the viral $\mathrm{S}$ protein $\mathrm{C}$-terminal domain containing a receptorbinding region that binds to the extracellular domain of ACE2 (Di Gennaro et al. 2020). Cleavage of the $\mathrm{S}$ protein by the host transmembrane serine protease 2 (TMPRSS2), to generate the $\mathrm{S} 1$ and S2 subunits, is a crucial step for the membrane fusion and viral internalization by endocytosis with ACE2 (Hoffmann et al. 2020) (Fig. 4). Interestingly, the interaction between $\mathrm{S}$ protein with the extracellular domain of ACE2, which triggers the endocytosis of the complex, is remarkably
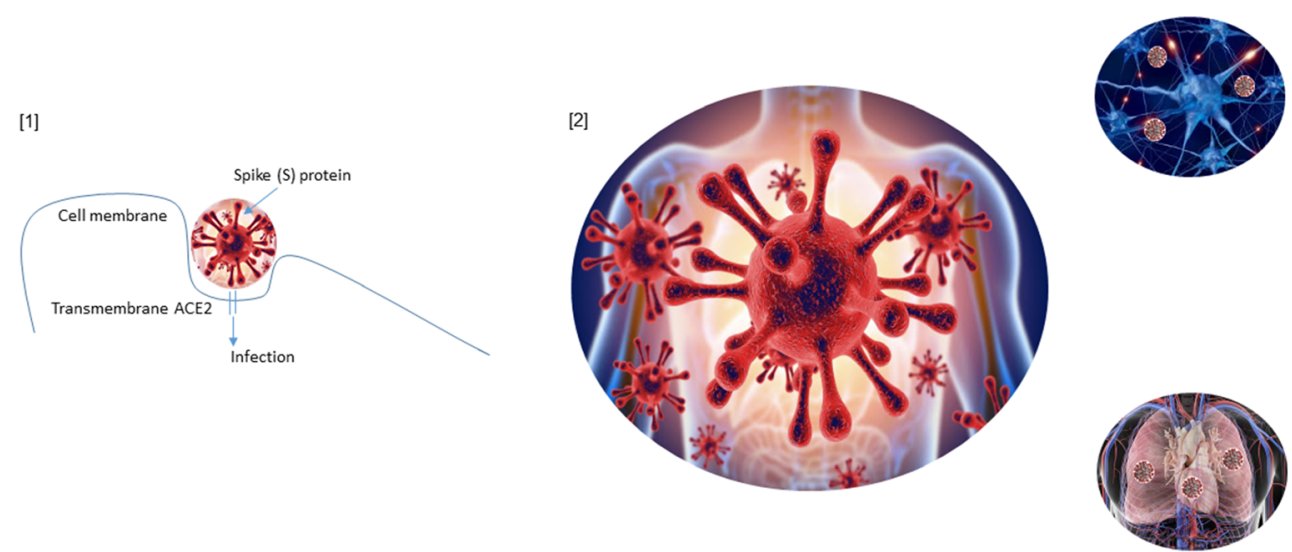

Fig. 4 Infection mechanism and tissue distribution of ACE2 receptors in humans. 1 The mechanism of the SARS-CoV-2 intracellular entry involves the viral Spike (S) protein C-terminal domain containing a receptor-binding region that binds to the extracellular domain of angiotensin-converting enzyme 2 (ACE2). Cleavage of the $\mathrm{S}$ protein by the host transmembrane serine protease 2 (TMPRSS2) is a crucial step for the membrane fusion and viral internalization by endocytosis with ACE2. 2 Different organs participate in COVID-19 due to the wide range expression of the primary SARS-CoV-2 entry receptor ACE2. ACE2 is particularly expressed on the type II alveolar epithelial cells, heart, and brain. The different distribution of ACE2 in organs and tissue is significantly correlated to the clinical symptoms of SARS-CoV-2 infection 
increased in patients suffering from hypertension or coronary heart disease (Svenningsen et al. 2017; Zheng et al. 2016). ACE2 internalization by SARS-CoV-2 results in the loss of ACE2 at the cell surface and removes a key pathway for the cell to degrade ANG II and generate the cardiovascularprotective Ang-(1-7). Certainly, an increase in the overall ratio of ANG II/Ang-(1-7), following ACE2 internalization, may exacerbate the pulmonary tissue damage, initially caused by SARS-CoV-2 (Guan et al. 2020a; Guan et al. 2020b; Huang et al. 2020; Yang et al. 2020a; Yang et al. 2020b; Yang et al. 2020c). Moreover, the down-regulation of ACE2 on the surface of infected cells might secondary imply an excessive response of the immune system and, then, the progression and the worsening of the disease in SARS-CoV-2infected patients. Lung and heart damage is due precisely by an overreaction of the immune system associated with a pronounced cytokine storm resulting into vascular inflammation, plaque instability, myocardial inflammation, and hypercoagulable state [(Levi et al. 2004; Prabhu 2004); Yang et al. 2020]. Clinical features include the dysregulation of $T$ helper cells of type 1 and 2 and levels extremely elevated of IL- 6 and ferritin (Liu et al. 2020; Yang et al. 2020a; Yang et al. 2020b; Yang et al. 2020c), which are also well-known markers for sepsis. The cardiovascular system involvement, during severe COVID-19, is unquestioned although the specific mechanisms remain to be explored. One proposed mode of action is related to a direct infection of cardiomyocytes (CMCs) by SARS-CoV-2 during the critical phase that leads to the myocarditis development (Zheng et al. 2020). A second assumption is that an over-activated immune system is predominantly contributing to SARS-CoV-2-induced heart damage. Following to cardiac ischemia as an effect of pneumonia and ARDS (Chen et al. 2020a; Chen et al. 2020b; Guan et al. 2020a; Guan et al. 2020b), CMC damage induces a range of pro-inflammatory mechanisms, which in turn escape control and further promote loss of CMCs (Mehta et al. 2020). Consequently, a secondary induced cardiac injury seems to be plausible. However, this scenario is strongly supported by previous studies investigating the SARS-CoV outbreak in 2002 or MERS-CoV-associated epidemic in 2012 (World Health Organization (WHO) 2020), where acute myocarditis and heart failure have also been reported (Alhogbani 2016). Considering the multiple effects on the heart, it can be assumed that previous cardiovascular diseases (CVDs) could lead to worse progression of COVID-19 and to an increased risk of mortality (Long et al. 2020). Interestingly, the increased mortality rate in patients with preexisting or new cardiac injuries is concomitant with high levels of troponin $\mathrm{T}$ (TnT) serum, a common cardiac damage biomarker. To support this hypothesis, the study of Guo and colleagues reported that CVD patients, without significantly raised TnT serum levels, presented only a slightly increased mortality compared to patients without CVDs (Guo et al. 2020). Therefore, although TnT levels should always be monitored in the case of cardiac damage caused by comorbidities (hypertension, diabetes, cardiovascular but also pulmonary dysfunctions, cancer, nephrological and cerebrovascular disorders) or severe disease progression, these levels should be critically interpreted since some medications and interventions can cause an upregulation of TnT (Cardiology Magazine 2020; Harvell et al. 2016). Together with the inflammatory cytokine IL-6 and ferritin, TnT may be used to predict the outcome of the SARS-CoV-2 infection and help to reduce COVID-19 mortality (Poe et al. 2015; Rivara et al. 2012).

\section{Neurological implications}

A growing body of clinical findings suggest that SARS-CoV2 gain entry into the central nervous system (CNS) (Mao et al. 2020), but the exact route of access has yet to be demonstrated. According to similarity with other coronaviruses, including MERS-CoV and SARS-CoV and studies in animal model of infection (Netland et al. 2008), CNS invasion was postulated to occur mainly by trans-synaptic transfer of virus particles, starting from infection in the peripheral nerve endings such as the olfactory ones (Butowt and Bilinska 2020). Along this line, peripheral neuronal manifestations, as the loss of smell and taste, are frequently experienced by COVID-19 individuals (Baig et al. 2020; Mao et al. 2020). The expression of ACE2 on the surface on neurons and glial cells (Hamming et al. 2004) (Fig. 2) as well as the priming proteases TMPRSS2 and furin, all required for virus attach and entry in host cells (Hoffmann et al. 2020; Lashley et al. 2008) makes them suitable targets for virus infection. However, recent findings from a postmortem study (Paniz-Mondolfi et al. 2020) support the hypothesis that the virus could also exploit the hematogenous route, since SARS-CoV-2 was found in neurons and capillary endothelial cells of the frontal lobe of a patient death for SARS-CoV2-associated ARDS. It is known that endothelial cells of blood vessels, including the cerebral ones, express ACE2. Thus, SARS-CoV-2 could infect those cells in the cerebral blood vessels, leading to increased permeability of the blood brain barrier (BBB) and in turn promoting pathogen invasion into the brain. A similar effect may be exerted indirectly by the virus-induced inflammatory cytokine storms, leading to brain edema and intracranial hypertension. Finally, the virus might also exploit a macrophage-mediated Trojan-horse mechanism (Santiago-Tirado and Doering 2017) or the lymphatic route to reach the brain, as well as other organs.

Several COVID-19 patients showed secondary mild neurological symptoms, including headache, dizziness, and neuralgia, whereas some severe cases showed neurological complications such as encephalopathy and acute cerebrovascular diseases (Ahmad and Rathore 2020). 
Along this context, besides other primary neurological manifestations such as seizures, increasing evidence indicate that SARS-CoV-2 can cause meningitis and encephalitis. Several reports documented encephalitis without cerebrospinal fluid (CSF) virus detection in COVID-19 patients (Bernard-Valnet et al. 2020; Dogan et al. 2020; Duong et al. 2020; Ye et al. 2020). Poyiadji and colleagues reported the first US presumptive case of COVID-19associated acute hemorrhagic necrotizing encephalopathy (Poyiadji et al. 2020), a rare encephalopathy previously associated with Influenza A virus (IAV) and potentially related to damaging effects of the virus-induced cytokine storm on BBB and brain parenchyma (Bailey 2020). The MRI brain of this SARS-CoV-2-positive 50-year-old female patient with a 3-day history of cough, fever, and altered mental status showed hemorrhagic rim resulting in lesions within the bilateral thalami, medial temporal lobes, and sub-insular brain regions. CSF samples resulted negative for bacteria and herpesviruses, but no investigation was performed either for IAV or SARS-CoV-2 presence. Bernard-Valnet and colleagues described two patients who developed a meningoencephalitis few days after a diagnosis of SARS-CoV-2 infection. At first, their symptoms were the classic ones of COVID-19 patients, including mild respiratory symptoms. Then, they developed severe neuropsychological symptoms, compatible with viral meningoencephalitis. However, no viruses, including SARSCoV-2, were detected in their CSF samples (BernardValnet et al. 2020). Another case was reported in Iran, where a hospitalized 79-year-old male, with history of fever and cough and positive for SARS-CoV-2, entered in a semi-conscious state probably due to a massive intracerebral hemorrhage in the right hemisphere with intraventricular and subarachnoid extension, as revealed with computed tomography scan. The authors did not report results from CSF analysis, but just hypothesized that SARSCoV-2 may directly invades the CNS via the olfactory receptors of cranial nerve I in the nasal cavity cell membrane (Sharifi-Razavi et al. 2020). Dogan and colleagues documented 6 cases of SARS-COV2-related autoimmune meningoencephalitis among the 29 most severely affected COVID-19 patients (intubated) of the 332 ones admitted to their center. Despite CSF samples did not show the occurrence of active CNS infection, including SARS-CoV-2, clinical tests evidenced increased levels of acuteinflammation (high ferritin, fibrinogen, CRP, and IL-6 in sera) and bilateral cerebral inflammation compatible with meningoencephalitis on MRI (Dogan et al. 2020).

Very recently, Pilotto and colleagues described the case of a SARS-CoV-2-positive 60-year-old Italian patient with a transient akinetic mutism due to encephalitis. The analysis of CSF, negative for several neurotropic viruses such as herpes (HSV-1 and 2, HHV-6, HHV-8, EBV, VZV), adenovirus, enterovirus, and Sars-CoV-2, revealed the high presence of proinflammatory cytokines, such as IL-6, TNF- $\alpha$, IL- 8 , and pleocytosis, suggesting a possible cytokine-mediated hyperinflammation response to SARS-COV2 infection (Pilotto et al. 2020). Interestingly, additional cases have been supported by positive virus detection in CSF. Morigughi and colleagues described the occurrence of meningoencephalitis (diagnosis of aseptic encephalitis) in a 24-year-old male patient with SARS-CoV2 RNA positive detection in CSF samples, but not in nasopharyngeal swab. This man was found unconsciousness and with a stiff neck 9 days after symptom onset (headache, fever, and generalized fatigue at day 1 , treated with antiviral and antipyretics under a first diagnosis of influenza; additional symptoms were worsening headache and sore throat at day 5) and experienced a transient generalized seizure during emergency transport to the hospital, and multiple epileptic seizures during emergency hospitalization. He had high CSF pressure $\left(320 \mathrm{mmH}_{2} \mathrm{O}\right)$ and no evidence of brain edema. Further brain MRI revealed right lateral ventriculitis and encephalitis mainly on right mesial lobe and hippocampus and panparanasal sinusitis. Authors claimed that the symptoms of encephalitis and cerebropathia should be considered as first indication, as the respiratory ones, for the diagnosis of hidden COVID-19 patients, and suggest the importance to pay attention to nasal and paranasal condition in the diagnosis and treatment for SARS-CoV-2 (Moriguchi et al. 2020).

Huang and colleagues, by updating what described by Duong and colleagues (Duong et al. 2020), also reported a case of SARS-CoV2 encephalitis (first CSF analysis negative for herpesviruses and other microbes, subsequent CSF analysis positive for SARS-COV2) in a US 41-year-old woman with some comorbidities (type 2 diabetes mellitus and obesity) whose nasopharyngeal swab on hospital admission was positive for SARS-CoV-2 and negative for influenza A and B viruses. This woman presented fever, headache, and new seizure onset and experienced no respiratory distress nor potential virus-induced abnormalities in other organs. Neurologically, she had hallucination and disorientation, followed by lethargic status but gradually improved after hydrochlorine treatment up to showing no neurologic symptoms within by day 12 of hospitalization (Huang et al. 2020b).

\section{Kawasaki outbreaks during COVID-19}

Although clinical manifestations of COVID-19 children were generally less severe than those of adult patients, young children, particularly infants, were vulnerable to SARS-CoV-2 infection. In children, the respiratory involvement appears to have a more benign course, with almost no fatalities reported in this age group (Dong et al. 2020; Nicastro et al. 2020; Yonker et al. 2020).

However, as observed in adults, also in children, the respiratory tract seems not to be the only system susceptible to 
SARS-CoV-2 infection (Xiao et al. 2020), and the tissue damage during COVID-19 is mostly mediated by the host innate immunity and by a cytokine storm (D'Antiga 2020; Henderson et al. 2020; Mehta et al. 2020). Kawasaki disease is an acute and typically self-limiting vasculitis, which almost exclusively interest children (Kawasaki et al. 1974). Patients with Kawasaki disease, during the acute phase, might have instability at hemodynamic level, a condition known as Kawasaki disease shock syndrome (KDSS) (Kanegaye et al. 2009). Other patients with Kawasaki disease might present macrophage activation syndrome (MAS) (Wang et al. 2015). The cause of Kawasaki disease remains unknown although the most accredited hypothesis supports an aberrant response of the immune system to one or more unidentified pathogens in genetically predisposed patients (Rowley 2018; Shulman and Rowley 2015). In Japan, during three epidemics in 1979, 1982, and 1986, the highest Kawasaki disease incidence was reported in January, suggesting that factors, during winter months, could trigger Kawasaki disease. During the SARSCoV-2 pandemic in Italy, as reported by Verdoni and colleagues, a high number of Kawasaki-like disease cases (features of patients with Kawasaki disease diagnosed during the COVID-19 pandemic appeared to differ from canonical cohort of Kawasaki patients) occurred after the first case of COVID-19 diagnosed in Bergamo, with a monthly incidence at least 30 times greater than the monthly incidence of the previous 5 years (Verdoni et al. 2020).

In the past 20 years, it has been proposed that viruses of the CoVs family may be implicated in the pathogenesis of Kawasaki disease. In 2005, the New Haven coronavirus (HCoV-NH) has been found in the respiratory secretions of 8 of 11 children with Kawasaki disease versus 22 controls tested (Esper et al. 2005). Skepticism on this association was expressed by a group from Japan, who did a retrospective study on nasopharyngeal swabs from 19 children with Kawasaki disease and 208 controls with respiratory tract infections. HCoV-NH RNA was found only in 5 of 208 controls versus 0 of 19 children with Kawasaki disease (Ebihara et al. 2005; Esper et al. 2005; Turnier et al. 2015). Another Japanese group explored, by serological tests, the association between HCoV-NL63 and HCoV-229E and Kawasaki disease. No difference in HCoV-NL63 antibody positivity between patients and controls was detected, whereas a higher HCoV-229E antibody positivity was reported in patients with Kawasaki disease (Shirato et al. 2014). This data suggests that the CoVs family could represent one of the triggers of Kawasaki disease. In the study of Verdoni and colleagues, the presence of the virus was confirmed by the antibodies research versus SARS-CoV-2 in 8 of 10 patients affected by Kawasaki disease. In the remaining two patients, the researchers speculated that confounding factors, such as the serological test performed after an infusion of high-dose immunoglobulins, played a role (Verdoni et al. 2020). Only 2 of 10 patients presented a naso-oropharyngeal swabs positive for SARSCoV-2 RNA and the positivity of IgG antibodies. These findings suggest a late onset of the disease compared with the primary infection. This could be the reason why, in the past, no active viral infection could be demonstrated in this disease (Verdoni et al. 2020). All these results and considerations could support the hypothesis that the immune response to SARS-CoV-2 is responsible for a Kawasaki-like disease in susceptible patients. Since patients diagnosed with Kawasaki-like disease after the viral spreading revealed a severe course, including KDSS and MAS, requiring adjunctive steroid treatment, genetic studies, in larger groups, should be done in order to investigate the susceptibility of patients developing this disease to the triggering effect of SARS-CoV-2.

Funding information Carla Prezioso was supported by Italian Ministry of Health (starting Grant: SG-2018-12366194).

Data Availibility No datasets were generated during the study.

\section{Compliance with ethical standards}

Competing interests The authors declare that they have no competing interests.

Open Access This article is licensed under a Creative Commons Attribution 4.0 International License, which permits use, sharing, adaptation, distribution and reproduction in any medium or format, as long as you give appropriate credit to the original author(s) and the source, provide a link to the Creative Commons licence, and indicate if changes were made. The images or other third party material in this article are included in the article's Creative Commons licence, unless indicated otherwise in a credit line to the material. If material is not included in the article's Creative Commons licence and your intended use is not permitted by statutory regulation or exceeds the permitted use, you will need to obtain permission directly from the copyright holder. To view a copy of this licence, visit http://creativecommons.org/licenses/by/4.0/.

\section{References}

Ahmad I, Rathore FA (2020) Neurological manifestations and complications of COVID-19: a literature review. J Clin Neurosci. https://doi. org/10.1016/j.jocn.2020.05.045

Alhogbani T (2016) Acute myocarditis associated with novel Middle East respiratory syndrome coronavirus. Ann Saudi Med 36(1):78-80. https://doi.org/10.5144/0256-4947.2016.78

Assiri A, Al-Tawfiq JA, Al-Rabeeah AA, Al-Rabiah FA, Al-Hajjar S, AlBarrak A, Flemban H, Al-Nassir WN, Balkhy HH, Al-Hakeem RF, Makhdoom HQ, Zumla AI, Memish ZA (2013) Epidemiological, demographic, and clinical characteristics of 47 cases of Middle East respiratory syndrome coronavirus disease from Saudi Arabia: a descriptive study. Lancet Infect Dis 13(9):752-761. https://doi.org/10. 1016/S1473-3099(13)70204-4

Bai Y, Yao L, Wei T, Tian F, Jin DY, Chen L, Wang M (2020) Presumed asymptomatic carrier transmission of COVID-19. JAMA 323(14): 1406-1407. https://doi.org/10.1001/jama.2020.2565

Baig AM, Khaleeq A, Ali U, Syeda H (2020) Evidence of the COVID-19 virus targeting the CNS: tissue distribution, host-virus interaction, 
and proposed neurotropic mechanisms. ACS Chem Neurosci 11(7): 995-998. https://doi.org/10.1021/acschemneuro.0c00122

Bailey HE (2020) Acute necrotizing encephalopathy associated with influenza A. Neurodiagn J 60(1):41-49. https://doi.org/10.1080/ 21646821.2020 .1725864

Beniac DR, Andonov A, Grudeski E, Booth TF (2006) Architecture of the SARS coronavirus prefusion spike. Nat Struct Mol Biol 13(8): 751-752. https://doi.org/10.1038/nsmb1123

Bennardo F, Buffone C, Giudice A (2020) New therapeutic opportunities for COVID-19 patients with tocilizumab: possible correlation of interleukin-6 receptor inhibitors with osteonecrosis of the jaws. Oral Oncol 21:104659. https://doi.org/10.1016/j.oraloncology. 2020.104659

Bernard-Valnet R, Pizzarotti B, Anichini A, Demars Y, Russo E, Schmidhauser M, Cerutti-Sola J, Rossetti AO, Du Pasquier R (2020) Two patients with acute meningo-encephalitis concomitant to SARS-CoV-2 infection. Eur J Neurol. https://doi.org/10.1111/ ene. 14298

Butowt R, Bilinska K (2020) SARS-CoV-2: olfaction, brain infection, and the urgent need for clinical samples allowing earlier virus detection. ACS Chem Neurosci 11(9):1200-1203. https://doi.org/10. 1021/acschemneuro.0c00172

Cardiology Magazine. Troponin and BNP Use in COVID-19. Available via https://www.acc.org/latest-in-cardiology/articles/2020/03/18/15/ 25/troponin-and-bnp-use-in-covid19 Accessed on 17 May 2020

Cascella M, Rajnik M, Cuomo A, Dulebohn SC, Di Napoli, R (2020) Features, evaluation and treatment coronavirus (COVID-19). In: StatPearls, StatPearls publishing: Treasure Island, FL, USA Available via http://www.ncbi.nlm.nih.gov/books/NBK554776/

Chan JFW, Yuan S, Kok KH, To KKW, Chu H, Yang J, Xing F, Liu J, Yip CCY, Poon RWS, Tsoi HW, Lo SKF, Chan KH, Poon VKM, Chan WM, Ip JD, Cai JP, Cheng VCC, Chen H, Hui CKM, Yuen KY (2020) A familial cluster of pneumonia associated with the 2019 novel coronavirus indicating person-to-person transmission: a study of a family cluster. Lancet 395(10223):514-523. https://doi.org/10. 1016/S0140-6736(20)30154-9

Chang CK, Sue SC, Yu TH, Hsieh CM, Tsai CK, Chiang YC, Lee SJ, Hsiao HH, Wu WJ, Chang WL, Lin CH, Huang TH (2006) Modular organization of SARS coronavirus nucleocapsid protein. J Biomed Sci 13(1):59-72

Chen Y, Chan KH, Kang Y, Chen H, Luk HK, Poon RW, Chan JFW, Yuen KY, Xia N, Lau SKP, Woo PCY (2015) A sensitive and specific antigen detection assay for Middle East respiratory syndrome coronavirus. Emerg Microbes Infect 4(4):e26. https://doi. org/10.1038/emi.2015.26

Chen C, Zhang XR, Ju ZY, He WF (2020a) Advances in the research of cytokine storm mechanism induced by corona virus disease 2019 and the corresponding immunotherapies. Zhonghua Shao Shang Za Zhi 36(0):E005. http://journal.yiigle.com/LinkIn.do?linkin_type= pubmed\&amp

Chen N, Zhou M, Dong X, Qu J, Gong F, Han Y, Qiu Y, Wang J, Liu Y, Wei Y, Xia J, Yu T, Zhang X, Zhang L (2020b) Epidemiological and clinical characteristics of 99 cases of 2019 novel coronavirus pneumonia in Wuhan, China: a descriptive study. Lancet 395(10223):507-513. https://doi.org/10.1016/S0140-6736(20) 30211-7

Cui L, Wang H, Ji Y, Yang J, Xu S, Huang X, Wang Z, Qin L, Tien P, Zhou X, Guo D, Chen Y (2015) The nucleocapsid protein of coronaviruses acts as a viral suppressor of RNA silencing in mammalian cells. J Virol 89(17):9029-9043

D'Antiga L (2020) Coronaviruses and immunosuppressed patients. The facts during the third epidemic Liver Transpl. https://doi.org/10. $1002 / 1$ t. 25756

de Wilde AH, Snijder EJ, Kikkert M, van Hemert MJ (2018) Host factors in coronavirus replication. Curr Top Microbiol Immunol 419:1-42. https://doi.org/10.1007/82_2017_25
DeDiego ML, Alvarez E, Almazán F, Rejas MT, Lamirande E, Roberts A, Shieh WJ, Zaki SR, Subbarao K, Enjuanes L (2007) A severe acute respiratory syndrome coronavirus that lacks the $\mathrm{E}$ gene is attenuated in vitro and in vivo. J Virol 81(4):1701-1713. https:// doi.org/10.1128/JVI.01467-06

Delmas B, Laude H (1990) Assembly of coronavirus spike protein into trimers and its role in epitope expression. J Virol 64(11):5367-5375

Di Gennaro F, Pizzol D, Marotta C, Antunes M, Racalbuto V, Veronese N, Smith L (2020) Coronavirus diseases (COVID-19) current status and future perspectives: a narrative review. Int J Environ Res Public Health 17(8):pii:E2690. https://doi.org/10.3390/ijerph17082690

Dogan L, Kaya D, Sarikaya T, Zengin R, Dincer A, Ozkan Akinci I, Afsar N (2020) Plasmapheresis treatment in COVID-19-related autoimmune meningoencephalitis: case series. Brain Behav Immun:pii: S0889-1591(20)30803-5. https://doi.org/10.1016/j.bbi.2020.05.022

Dong Y, Mo X, Hu Y, Qi X, Jiang F, Jiang Z, Tong S (2020) Epidemiology of COVID-19 among children in China. Pediatrics pii:e20200702. https://doi.org/10.1542/peds.2020-0702

Duong L, Xu P, Liu A (2020) Meningoencephalitis without respiratory failure in a young female patient with COVID-19 infection in downtown Los Angeles, early April 2020. Brain Behav Immun:pii: S0889-1591(20)30509-2. https://doi.org/10.1016/j.bbi.2020.04.024

Ebihara T, Endo R, Ma X, Ishiguro N, Kikuta H (2005) Lack of association between New Haven coronavirus and Kawasaki disease. J Infect Dis 192(2):351-352. https://doi.org/10.1086/430797

Esper F, Shapiro ED, Weibel C, Ferguson D, Landry ML, Kahn JS (2005) Association between a novel human coronavirus and Kawasaki disease. J Infect Dis 191(4):499-502. https://doi.org/10. 1086/428291

Fehr AR, Perlman S (2015) Coronaviruses: an overview of their replication and pathogenesis. Methods Mol Biol 1282:1-23. https://doi. org/10.1007/978-1-4939-2438-7 1

Ferguson NM, Laydon D, Nedjati-Gilani G, Natsuko I, Ainslie K, Baguelin M, Bhatia S, Boonyasiri A, Cucunubá Z, CuomoDannenburg G, Dighe A, Dorigatti I, Fu H, Gaythorpe K, Green W, Hamlet A, Hinsley W, Okell LC, van Elsland S, Thompson H, Verity R, Volz E, Wang H, Wang Y, Walker PGT, Walters C, Winskill P, Whittaker C, Donnelly CA, Riley S, Ghani AC (2020) Impact of non-pharmaceutical interventions (NPIs) to reduce COVID-19 mortality and healthcare demand. Imperial College COVID-19 Response Team (16 March 2020). https://doi.org/10. $25561 / 77482$

General Office of National Administration of Traditional Chinese Medicine (n.d.) Diagnostic and treatment protocol for Novel Coronavirus Pneumonia (Trial version 6) Available via http:// www.kankyokansen.org/uploads/uploads/files/jsipc/protocol_V6. pdf Accessed on 17 May 2020

Guan WJ, Liang WH, He JX, Zhong NS (2020a) Cardiovascular comorbidity and its impact on patients with Covid-19. Eur Respir J:pii: 2001227. https://doi.org/10.13039/501100007162

Guan WJ, Ni ZY, Hu Y, Liang WH, Ou CQ, He JX, Liu L, Shan H, Lei CL, DSC H, Du B, Li LJ, Zeng G, Yuen KY, Chen RC, Tang CL, Wang T, Chen PY, Xiang J, Li SY, Wang JL, Liang ZJ, Peng YX, Wei L, Liu Y, Hu YH, Peng P, Wang JM, Liu JY, Chen Z, Li G, Zheng ZJ, Qiu SQ, Luo J, Ye CJ, Zhu SY, Zhong NS, China Medical Treatment Expert Group for Covid-19 (2020b) Clinical Characteristics of Coronavirus Disease 2019 in China. N Engl J Med 382(18):1708-1720. https://doi.org/10.1056/ NEJMoa2002032?query=featured_home

Guo YR, Cao QD, Hong ZS, Tan YY, Chen SD, Jin HJ, Tan KS, Wang DY, Yan Y (2020) The origin, transmission and clinical therapies on coronavirus disease 2019 (COVID-19) outbreak - an update on the status. Mil Med Res 7(1):11. https://doi.org/10.1186/s40779-02000240-0

Hamming I, Timens W, Bulthuis ML, Lely AT, Navis G, van Goor H (2004) Tissue distribution of ACE2 protein, the functional receptor 
for SARS coronavirus. A first step in understanding SARS pathogenesis. J Pathol 203(2):631-637. https://doi.org/10.1002/path.1570

Harvell B, Henrie N, Ernst AA, Weiss SJ, Oglesbee S, Sarangarm D, Hernandez L (2016) The meaning of elevated troponin I levels: not always acute coronary syndromes. Am J Emerg Med 34(2): 145-148. https://doi.org/10.1016/S0735-6757(00)90317-6

Henderson LA, Canna SW, Schulert GS, Volpi S, Lee PY, Kernan KF, Caricchio R, Mahmud S, Hazen MM, Halyabar O, Hoyt KJ, Han J, Grom AA, Gattorno M, Ravelli A, De Benedetti F, Behrens EM, Cron RQ, Nigrovic PA (2020) On the alert for cytokine storm: immunopathology in COVID-19. Arthritis Rheumatol. https://doi. org/10.1002/art.41285

Hoffmann M, Kleine-Weber H, Schroeder S, Krüger N, Herrler T, Erichsen S, Schiergens TS, Herrler G, Wu NH, Nitsche A, Müller MA, Drosten C, Pöhlmann S (2020) SARS-CoV-2 cell entry depends on ACE2 and TMPRSS2 and is blocked by a clinically proven protease inhibitor. Cell 181(2):271-280.e8. https://doi.org/10. 1016/j.cell.2020.02.052 http://www.salute.gov.it/portale/news/p3 2111 .jsp? lingua $=$ italiano $\&$ menu $=$ notizie $\& p=$ dalministero $\& \mathrm{id}=$ $4 \overline{186}$ Accessed on 17 May 2020

Huang C, Wang Y, Li X, Ren L, Zhao J, Hu Y, Zhang L, Fan G, Xu J, Gu X, Cheng Z, Yu T, Xia J, Wei Y, Wu W, Xie X, Yin W, Li H, Liu M, Xiao Y, Gao H, Guo L, Xie J, Wang G, Jiang R, Gao Z, Jin Q, Wang J, Cao B (2020a) Clinical features of patients infected with 2019 novel coronavirus in Wuhan, China. Lancet 395(10223):497506. https://doi.org/10.1016/j.cell.2020.02.052

Huang YH, Jiang D, Huang JT (2020b) A case of COVID-19 encephalitis. Brain Behav Immun. https://doi.org/10.1016/j.bbi.2020.05.012

Hurst KR, Koetzner CA, Masters PS (2009) Identification of in vivointeracting domains of the murine coronavirus nucleocapsid protein. J Virol 83(14):7221-7234. https://doi.org/10.1128/JVI.00440-09

Italian Ministry of Health Covid-19, Gazzetta Ufficiale Decreto \# Iorestoacasa (10 March 2020) Available via http://www.salute. gov.it/portale/news/p3_2_1_1_1.jsp?lingua=italiano\&menu= notizie $\& \mathrm{p}=$ dalministero\&id $=4186$ Accessed on 17 may 2020

Italian National Institute of Health (ISS). Coronavirus Surveillance Bulletin May 4/20 Available via https://www.epicentro.iss.it/en/ coronavirus/bollettino/Infografica_4maggio\%20ENG.pdf. Accessed on 17 May 2020

Italian National Institute of Health (ISS) and National Institute of Statistics (May, 4th 2020) Available via https://www.istat.it/it/ files//2020/05/Istat-ISS-eng.pdf. Accessed on 17 May 2020

Kanegaye JT, Wilder MS, Molkara D, Frazer JR, Pancheri J, Tremoulet AH, Watson VE, Best BM, Burns JC (2009) Recognition of a Kawasaki disease shock syndrome. Pediatrics 123(5):e783-e789. https://doi.org/10.1542/peds.2008-1871

Kawasaki T, Kosaki F, Okawa S, Shigematsu I, Yanagawa H (1974) A new infantile acute febrile mucocutaneous lymph node syndrome (MLNS) prevailing in Japan. Pediatrics 54(3):271-276

Keidar S, Kaplan M, Gamliel-Lazarovich A (2007) ACE2 of the heart: from angiotensin I to angiotensin (1-7). Cardiovasc Res 73(3):463469. https://doi.org/10.1016/j.cardiores.2006.09.006

Lashley T, Revesz T, Plant G, Bandopadhyay R, Lees AJ, Frangione B, Wood NW, de Silva R, Ghiso J, Rostagno A, Holton JL (2008) Expression of BRI2 mRNA and protein in normal human brain and familial British dementia: its relevance to the pathogenesis of disease. Neuropathol Appl Neurobiol 34(5):492-505. https://doi. org/10.1111/j.1365-2990.2008.00935.x

Lee N, Hui D, Wu A, Chan P, Cameron P, Joynt GM, Ahuja A, Yung MY, Leung CB, To KF, Lui SF, Szeto CC, Chung S, Sung JJY (2003) A major outbreak of severe acute respiratory syndrome in Hong Kong. N Engl J Med 348(20):1986-1994. https://doi.org/10. 1056/NEJMoa030685

Lei J, Kusov Y, Hilgenfeld R (2018) Nsp3 of coronaviruses: structures and functions of a large multi-domain protein. Antivir Res 149:58-74
Letko M, Marzi A, Munster V (2020) Functional assessment of cell entry and receptor usage for SARS-CoV-2 and other lineage B betacoronaviruses. Nat Microbiol 5(4):562-569. https://doi.org/10. 1038/s41564-020-0688-y

Levi M, van der Poll T, Büller HR (2004) Bidirectional relation between inflammation and coagulation. Circulation 109(22):2698-2704. https://doi.org/10.1161/01.CIR.0000131660.51520.9A

Lim J, Jeon S, Shin HY, Kim MJ, Seong YM, Lee WJ, Choe KW, Kang YM, Lee B, Park SJ (2020) Case of the index patient who caused tertiary transmission of COVID-19 infection in Korea: the application of lopinavir/ritonavir for the treatment of COVID-19 infected pneumonia monitored by quantitative RT-PCR. J Korean Med Sci 35(6):e79. https://doi.org/10.3346/jkms.2020.35.e79

Ling Y, Xu SB, Lin YX, Tian D, Zhu ZQ, Dai FH, Wu F, Song ZG, Huang W, Chen J, Hu BJ, Wang S, Mao EQ, Zhu L, Zhang WH, Lu HZ (2020) Persistence and clearance of viral RNA in 2019 novel coronavirus disease rehabilitation patients. Chin Med J 133(9): 1039-1043. https://doi.org/10.1097/CM9.0000000000000774

Lippi G, Simundic AM, Plebani M (2020) Potential pre-analytical and analytical vulnerabilities in the laboratory diagnosis of coronavirus disease 2019 (COVID-19). Clin Chem Lab Med 0. https://doi.org/ 10.1515/cclm-2020-0285

Liu T, Zhang J, Yang Y, Ma H, Li Z, Zhang J, Cheng J, Zhang X, Zhao Y, Xia Z, Zhang L, Wu G, Yi J (2020) The potential role of IL-6 in monitoring severe case of coronavirus disease 2019. medRxiv. https://doi.org/10.1101/2020.03.01.20029769

Long B, Brady WJ, Koyfman A, Gottlieb M (2020) Cardiovascular complications in COVID-19. Am J Emerg Med pii S0735-6757(20): 30277-30271. https://doi.org/10.1016/j.ajem.2020.04.048

Lu R, Zhao X, Li J, Niu P, Yang B, Wu H, Wang W, Song H, Huang B, Zhu N, Bi Y, Ma X, Zhan F, Wang L, Hu T, Zhou H, Hu Z, Zhou W, Zhao L, Chen J, Meng Y, Wang J, Lin Y, Yuan J, Xie Z, Ma J, Liu WJ, Wang D, Xu W, Holmes EC, Gao GF, Wu G, Chen W, Shi W, Tan W (2020) Genomic characterisation and epidemiology of 2019 novel coronavirus: implications for virus origins and receptor binding. Lancet 395(10224):565-574. https://doi.org/10.1016/S01406736(20)30251-8

Lupia T, Scabini S, Mornese Pinna S, Di Perri G, De Rosa FG, Corcione S (2020) 2019 novel coronavirus (2019-nCoV) outbreak: a new challenge. J Glob Antimicrob Resist 21:22-27. https://doi.org/10. 1016/j.jgar.2020.02.021

Mao L, Jin H, Wang M, Yu H, Chen S, He Q, Chang J, Hong C, Zhou Y, Wang D, Miao X, Li Y, Hu B (2020) Neurological manifestations of hospitalized patients with coronavirus disease 2019 in Wuhan, China. JAMA Neurol e201127. https://doi.org/10.1001/ jamaneurol.2020.1127

Mehta P, McAuley DF, Brown M, Sanchez E, Tattersall RS, Manson JJ, HLH Across Speciality Collaboration, UK (2020) COVID-19: consider cytokine storm syndromes and immunosuppression. Lancet 395(10229):1033-1034. https://doi.org/10.1016/S0140-6736(20) 30628-0

Meyer B, Drosten C, Muller MA (2014) Serological assays for emerging coronaviruses: challenges and pitfalls. Virus Res 194:175-183. https://doi.org/10.1016/j.virusres.2014.03.018

Moriguchi T, Harii N, Goto J, Harada D, Sugawara H, Takamino J, Ueno M, Sakata H, Kondo K, Myose N, Nakao A, Takeda M, Haro H, Inoue O, Suzuki-Inoue K, Kubokawa K, Ogihara S, Sasaki T, Kinouchi H, Kojin H, Ito M, Onishi H, Shimizu T, Sasaki Y, Enomoto N, Ishihara H, Furuya S, Yamamoto T, Shimada S (2020) A first case of meningitis/encephalitis associated with SARS-Coronavirus-2. Int J Infect Dis 94:55-58. https://doi.org/10. 1016/j.ijid.2020.03.062

Nal B, Chan C, Kien F, Siu L, Tse J, Chu K, Kam J, Staropoli I, Crescenzo-Chaigne B, Escriou N, van der Werf S, Yuen KY, Altmeyer R (2005) Differential maturation and subcellular localization of severe acute respiratory syndrome coronavirus surface 
proteins S, M and E. J Gen Virol 86(Pt 5):1423-1434. https://doi. org/10.1099/vir.0.80671-0

National Microbiology Data Center. Available online: http://nmdc.cn/ coronavirus (Accessed on 17 May 2020)

Nejadi Babadaei MM, Hasan A, Haj Bloukh S, Edis Z, Sharifi M, Kachooei E, Falahati M (2020) The expression level of angiotensin-converting enzyme 2 determine the severity of COVID-19: lung and heart tissue as targets. J Biomol Struct Dyn 13:1-13. https://doi.org/10.1080/07391102.2020

Netland J, Meyerholz DK, Moore S, Cassell M, Perlman S (2008) Severe acute respiratory syndrome coronavirus infection causes neuronal death in the absence of encephalitis in mice transgenic for human ACE2. J Virol 82(15):7264-7275. https://doi.org/10.1128/JVI. 00737-08

Neuman BW, Kiss G, Kunding AH, Bhella D, Baksh MF, Connelly S, Droese B, Klaus JP, Makino S, Sawicki SG, Siddell SG, Stamou DG, Wilson IA, Kuhn P, Buchmeier MJ (2011) A structural analysis of $\mathrm{M}$ protein in coronavirus assembly and morphology. J Struct Biol 174(1):11-22. https://doi.org/10.1016/j.jsb.2010.11.021

Nicastro E, Mazza A, Gervasoni A, Di Giorgio A, D’Antiga L (2020) A pediatric emergency department protocol to avoid intrahospital dispersal of SARS-CoV-2 during the outbreak in Bergamo. Italy $\mathrm{J}$ Pediatr. https://doi.org/10.1016/j.jpeds.2020.04.026

Nieto-Torres JL, DeDiego ML, Verdiá-Báguena C, Jimenez-Guardeño JM, Regla-Nava JA, Fernandez-Delgado R, Castaño-Rodriguez C, Alcaraz A, Torres J, Aguilella VM, Enjuanes L (2014) Severe acute respiratory syndrome coronavirus envelope protein ion channel activity promotes virus fitness and pathogenesis. PLoS Pathog 10(5): e1004077. https://doi.org/10.1371/journal.ppat.1004077

Pan X, Chen D, Xia Y, Wu X, Li T, Ou X, Zhou L, Liu J (2020) Asymptomatic cases in a family cluster with SARS-CoV-2 infection. Lancet Infect Dis 20(4):410-411. https://doi.org/10.1016/ S1473-3099(20)30114-6

Paniz-Mondolfi A, Bryce C, Grimes Z, Gordon RE, Reidy J, Lednicky J, Sordillo EM, Fowkes M (2020) Central nervous system involvement by severe acute respiratory syndrome coronavirus -2 (SARS-CoV-2). J Med Virol. https://doi.org/10.1002/jmv.25915

Patel R, Babady E, Theel ES, Storch GA, Pinsky BA, St. George K, Smith TC, Bertuzzi S (2020) Report from the American Society for Microbiology COVID-19 International Summit, 23 March 2020: Value of Diagnostic Testing for SARS-CoV-2/ COVID-19. mBio 11(2):e00722-20. https://doi.org/10.1101/2020. 03.13 .990226

Pathan N, Hemingway CA, Alizadeh AA, Stephens AC, Boldrick JC, Oragui EE, McCabe C, Welch SB, Whitney A, O'Gara P, Nadel S, Relman DA, Harding SE, Levin M (2004) Role of interleukin 6 in myocardial dysfunction of meningococcal septic shock. Lancet 363 : 203-209. https://doi.org/10.1016/S0140-6736(03)15326-3

Paules CI, Marston HD, Fauci AS (2020) Coronavirus infections - more than just the common cold. JAMA. 323:707. https://doi.org/10. 1001/jama.2020.0757

Pilotto A, Odolini S, Masciocchi S, Comelli A, Volonghi I, Gazzina S, Nocivelli S, Pezzini A, Focà E, Caruso A, Leonardi M, Pasolini MP, Gasparotti R, Castelli F, Padovani A (2020) Steroid-responsive severe encephalopathy in SARS-CoV-2 infection. medRxiv. https:// doi.org/10.1101/2020.04.12.20062646.t

Poe S, Vandivier-Pletsch RH, Clay M, Wong HR, Haynes E, Rothenberg FG (2015) Cardiac troponin measurement in the critically ill: potential for guiding clinical management. J Investig Med 63(8):905-915 https:/www.ncbi.nlm.nih.gov/pubmed/26425879

Poyiadji N, Shahin G, Noujaim D, Stone M, Patel S, Griffith B (2020) COVID-19-associated acute hemorrhagic necrotizing encephalopathy: CT and MRI features. Radiology:201187. https://doi.org/10. 1148/radiol.2020201187
Prabhu SD (2004) Cytokine-induced modulation of cardiac function. Circ Res 95(12):1140-1153. https://doi.org/10.1161/01.RES. 0000150734.79804 .92

Pyle CJ, Uwadiae FI, Swieboda DP, Harker JA (2017) Early IL-6 signalling promotes IL-27 dependent maturation of regulatory T cells in the lungs and resolution of viral immunopathology. PLoS Pathog 13(9):e1006640. https://doi.org/10.1371/journal.ppat.1006640

Report of the WHO-China Joint Mission on Coronavirus Disease 2019 (COVID-19) 16-24 February 2020, Available via https://www.who. int/publications-detail/report-of-the-who-china-joint-mission-oncoronavirus-disease-2019-(covid-19) Accessed on 17 May 2020

Rivara MB, Bajwa EK, Januzzi JL, Gong MN, Thompson BT, Christiani DC (2012) Prognostic significance of elevated cardiac troponin-T levels in acute respiratory distress syndrome patients. PLoS One 7(7):e40515. https://doi.org/10.1371/journal.pone.0040515.t001

Rose-John S (2018) Interleukin-6 family cytokines. Cold Spring Harb Perspect Biol 10(2):pii:a028415. https://doi.org/10.1101/ cshperspect.a028415

Rothe C, Schunk M, Sothmann P, Bretzel G, Froeschl G, Wallrauch C, Zimmer T, Thiel V, Janke C, Guggemos W, Seilmaier M, Drosten C, Vollmar P, Zwirglmaier K, Zange S, Wölfel R, Hoelscher M (2020) Transmission of 2019-nCoV infection from an asymptomatic contact in Germany. N Engl J Med 382(10):970-971. https://doi. org/10.1056/NEJMc2001468

Rowley AH (2018) Is Kawasaki disease an infectious disorder? Int $\mathbf{J}$ Rheum Dis 21(1):20-25. https://doi.org/10.1111/1756-185X.13213

Santiago-Tirado FH, Doering TL (2017) False friends: phagocytes as Trojan horses in microbial brain infections. PLoS Pathog 13(12): e1006680. https://doi.org/10.1371/journal.ppat.1006680

Santos RAS, Sampaio WO, Alzamora AC, Motta-Santos D, Alenina N, Bader M, Campagnole-Santos MJ (2018) The ACE2/angiotensin(1-7)/MAS Axis of the renin-angiotensin system: focus on angiotensin-(1-7). Physiol Rev 98(1):505-553. https://doi.org/10.1152/ physrev.00023.2016

Sharifi-Razavi A, Karimi N, Rouhani N (2020) COVID-19 and intracerebral haemorrhage: causative or coincidental? New Microbes New Infect 35:100669. https://doi.org/10.1016/j.nmni.2020.100669

Shirato K, Imada Y, Kawase M, Nakagaki K, Matsuyama S, Taguchi F (2014) Possible involvement of infection with human coronavirus 229E, but not NL63, in Kawasaki disease. J Med Virol 86(12): 2146-2153. https://doi.org/10.1002/jmv.23950

Shulman ST, Rowley AH (2015) Kawasaki disease: insights into pathogenesis and approaches to treatment. Nat Rev Rheumatol 11(8): 475-482. https://doi.org/10.1038/nrrheum.2015.54

Song Z, Xu Y, Bao L, Zhang L, Yu P, Qu Y, Zhu H, Zhao W, Han Y, Qin C (2019) From SARS to MERS, thrusting coronaviruses into the spotlight. Viruses 11(1):pii:E59. https://doi.org/10.3390/v11010059

Svenningsen P, Hinrichs GR, Zachar R, Ydegaard R, Jensen BL (2017) Physiology and pathophysiology of the plasminogen system in the kidney. Pflugers Arch 469(11):1415-1423. https://doi.org/10.1007/ s00424-017-2014-y

Tanaka T, Narazaki M, Kishimoto T (2016) Immunotherapeutic implications of IL-6 blockade for cytokine storm. Immunotherapy 8:959970. https://doi.org/10.2217/imt-2016-0020

Turnier JL, Anderson MS, Heizer HR, Jone PN, Glodé MP, Dominguez SR (2015) Concurrent respiratory viruses and Kawasaki disease. Pediatrics 136(3):e609-e614. https://doi.org/10.1542/peds.2015-0950

Verdoni L, Mazza A, Gervasoni A, Martelli L, Ruggeri M, Ciuffreda M, Bonanomi E, D'Antiga L (2020) An outbreak of severe Kawasaki like disease at the Italian epicentre of the SARS-CoV-2 epidemic: an observational cohort study. Lancet. https://doi.org/10.1016/S01406736(20)31103-X

Wang Z, Xu X (2020) scRNA-seq profiling of human testes reveals the presence of the ACE2 receptor, a target for SARS-CoV-2 infection in Spermatogonia, Leydig and Sertoli cells. Cells 9(4):pii:E920. https://doi.org/10.3390/cells9040920 
Wang W, Gong F, Zhu W, Fu S, Zhang Q (2015) Macrophage activation syndrome in Kawasaki disease: more common than we thought? Semin Arthritis Rheum 44(4):405-410. https://doi.org/10.1016/j. semarthrit.2014.07.007

Wang H, Xiao X, Lu J, Chen Z, Li K, Liu H, Luo L, Wang M, Yang (2016) Factors associated with clinical outcome in 25 patients with avian influenza a (H7N9) infection in Guangzhou, China. BMC Infect Dis 16(1):534. https://doi.org/10.1186/s12879-016-1840-4

Weiss SR, Leibowitz JL (2011) Coronavirus pathogenesis. Adv Virus Res 81:85-164. https://doi.org/10.1016/B978-0-12-385885-6. 00009-2

WHO Summary of probable SARS cases with onset of illness from 1 November 2002 to 31 July 2003. Available via https://www.who. int/csr/sars/country/table2004_04_21/en/. Accessed on 17 May 2020

WHO Coronavirus disease 2019a (COVID-19) Situation Report - 26 (15 February 2020) Available via https:// www.who.int/docs/defaultsource/coronaviruse/situationreports/20200215-sitrep-26 covid19. pdf?s fvrsn=a4cc6787_2 Accessed on 17 May 2020

WHO Coronavirus disease 2019b (COVID-19) Situation Report - 51 (11 March 2020) Available via https://www.who.int/emergencies/ diseases/novel-coronavirus-2019/situation-reports Accessed on 17 May 2020

WHO Middle East respiratory syndrome coronavirus (MERS-CoV) monthly summary, November 2019. Available via https://www. who.int/emergencies/mers-cov/en/ Accessed on 17 May 2020

World Health Organization (2020) Coronavirus disease 2019 (COVID19) situation report-112 (11 May 2020) Available via https://www. who.int/docs/default-source/coronaviruse/20200302-sitrep-42covid-19.pdf?sfvrsn=d863e045_2 Accessed on 17 May 2020

World Health Organization (WHO). Summary of probable SARS cases with onset of illness from 1 November 2002 to 31 July. Available via https:/www.who.int/csr/sars/country/table2004_04_21/en/ Accessed on 17 May 2020

World Health Organization (WHO). Background and summary of novel coronavirus infection - as of 30 November 2012. Available via https://www.who.int/csr/disease/coronavirus_infections/update 20121130/en/ Accessed on 17 May 2020

World Health Organization Coronavirus Disease (COVID-19) Technical Guidance: Laboratory Testing for 2019-nCoV in Humans. Available via https://www.who.int/emergencies/diseases/novelcoronavirus-2019/technical-guidance/laboratory-guidance Accessed on 17 May 2020

Wu F, Zhao S, Yu B, Chen YM, Wang W, Hu Y, Song ZG, Tao ZW, Tian JH, Pei YY, Yuan ML, Zhang YL, Dai FH, Liu Y, Wang QM, Zheng JJ, Xu L, Holmes EC, Yong-Zhen Zhang YZ (2020) Complete genome characterisation of a novel coronavirus associated with severe human respiratory disease in Wuhan. China bioRxiv. https://doi.org/10.1101/2020.01.24.919183

Xiao F, Tang M, Zheng X, Liu Y, Li X, Shan H (2020) Evidence for gastrointestinal infection of SARS-CoV-2. Gastroenterology 158(6):1831-1833.e3. https://doi.org/10.1053/j.gastro.2020.02.055

Yang C, Jin Z (2020) An acute respiratory infection runs into the most common noncommunicable epidemic COVID-19 and cardiovascular diseases. JAMA Cardiol. https://doi.org/10.1001/ jamacardio.2020.0934

Yang J, Zheng Y, Gou X, Pu K, Chen Z, Guo Q, Ji R, Wang H, Wang Y, Zhou Y (2020a) Prevalence of comorbidities and its effects in coronavirus disease 2019 patients: a systematic review and meta-analysis. Int J Infect Dis 94:91-95. https://doi.org/10.1016/j.ijid.2020.03.017

Yang X, Yu Y, Xu J, Shu H, Liu H, Wu Y, Zhang L, Yu Z, Fang M, Yu T (2020b) Clinical course and outcomes of critically ill patients with SARS-CoV-2 pneumonia in Wuhan, China: a single-centered, retrospective, observational study. Lancet Respir Med 8(5):475-481. https://doi.org/10.1016/S2213-2600(20)30079-5

Yang Y, Peng F, Wang R, Guan K, Jiang T, Xu G, Sun J, Chang C (2020c) The deadly coronaviruses: the 2003 SARS pandemic and the 2020 novel coronavirus epidemic in China. J Autoimmun 109: 102434. https://doi.org/10.1016/j.jaut.2020.102434

Ye M, Ren Y, Lv T (2020) Encephalitis as a clinical manifestation of COVID-19. Brain Behav Immun pii S0889-1591(20):3046530467. https://doi.org/10.1016/j.bbi.2020.04.017

Yonker LM, Shen K, Kinane TB (2020) Pediatr lessons unfolding from pediatric cases of COVID-19 disease caused by SARS-CoV-2 infection. Pediatr Pulmonol 55(5):1085-1086. https://doi.org/10. 1002/ppul.24748

Yuefei J, Haiyan Y, Wangquan J, Weidong W, Shuaiyin C, Weiguo Z, Guangcai D (2020) Virology, epidemiology, pathogenesis, and control of COVID-19. Viruses 12(4):E372. https://doi.org/10.3390/ v12040372

Zhao Y, Zhao Z, Wang Y, Zhou Y, Ma Y, Zuo W (2020) Single-cell RNA expression profiling of ACE2, the putative receptor of Wuhan 2019-nCov. bioRxiv. https://doi.org/10.1101/2020.01.26.919985

Zheng H, Liu X, Sharma NM, Li Y, Pliquett RU, Patel KP (2016) Urinary Proteolytic activation of renal epithelial $\mathrm{Na}+$ channels in chronic heart failure. Hypertension 67(1):197-205. https://doi.org/10.1161/ HYPERTENSIONAHA

Zheng YY, Ma YT, Zhang JY, Xie X (2020) COVID-19 and the cardiovascular system. Nat Rev Cardiol 17(5):259-260. https://doi.org/10. 1038/s41569-020-0360-5

Zhou P, Yang XL, Wang XG, Hu B, Zhang L, Zhang W, Si HR, Zhu Y, Li B, Huang CL, Chen HD, Chen J, Luo Y, Guo H, Jiang RD, Liu MQ, Chen Y, Shen XR, Wang X, Zheng XS, Zhao K, Chen QJ, Deng F, Liu LL, Yan B, Zhan FX, Wang YY, Xiao GF, Shi ZL (2020) A pneumonia outbreak associated with a new coronavirus of probable bat origin. Nature 579(7798):270-273. https://doi.org/10. 1038/s41586-020-2012-7

Zhu N, Zhang D, Wang W, Li X, Yang B, Song J, Zhao X, Huang B, Shi W, Lu R, Niu P, Zhan F, Ma X, Wang D, Xu W, Wu G, Gao GF, Tan W, China Novel Coronavirus Investigating and Research Team (2020) A novel coronavirus from patients with pneumonia in China, 2019. N Engl J Med 382(8):727-733. https://doi.org/10.1056/ NEJMoa2001017

Publisher's note Springer Nature remains neutral with regard to jurisdictional claims in published maps and institutional affiliations. 